
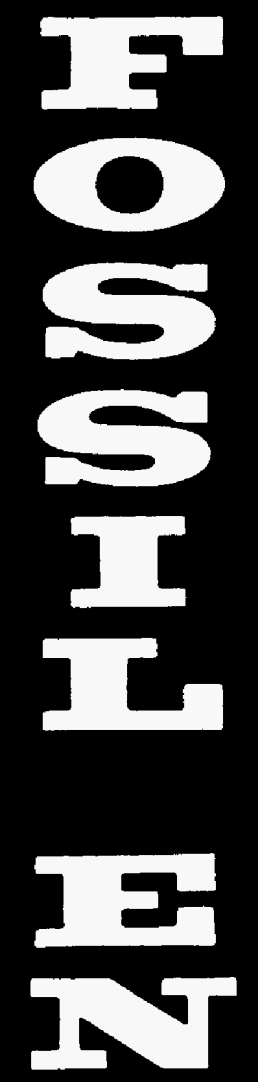

12
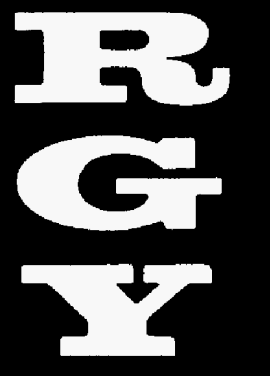

Work Performed Under Contract No. FEW 8242

Sandia National Laboratories

Albuquerque, New Mexico

Final Report

October 2000

By

Brian Ehgartner

Vince Tidwell

Date Published: February 2001
DOE/FEW 8242-1

(OSTI ID: 774489)

MULTIPHASE FLOW AND CAVERN ABANDONMENT IN SALT

National Petroleum Technology Office U.S. DEPARTMENT OF ENERGY Tulsa, Oklahoma 


\section{DISCLAIMER}

This report was prepared as an account of work sponsored by an agency of the United States Government. Neither the United States Government nor any agency thereof, nor any of their employees, makes any warranty, expressed or implied, or assumes any legal liability or responsibility for the accuracy, completeness, or usefulness of any information, apparatus, product, or process disclosed, or represents that its use would not infringe privately owned rights. Reference herein to any specific commercial product, process, or service by trade name, trademark, manufacturer, or otherwise does not necessarily constitute or imply its endorsement, recommendation, or favoring by the United States Government or any agency thereof. The views and opinions of authors expressed herein do not necessarily state or reflect those of the United States Government.

This report has been reproduced directly from the best available copy. 
DOE/FEW 8242-1

Distribution Category UC-122

Multiphase Flow and Cavern Abandonment in Salt

\author{
By \\ Brian Ehgartner \\ Vince Tidwell
}

February 2001

FEW 8242

Prepared for

U.S. Department of Energy

Assistant Secretary for Fossil Energy

John Ford, Project Manager

National Petroleum Technology Office

P.O. Box 3628

Tulsa, OK 74101

Prepared by

Sandia National Laboratories

P.O. Box 5800, MS 1033

Albuquerque, NM 87185-1033 
Table of Contents

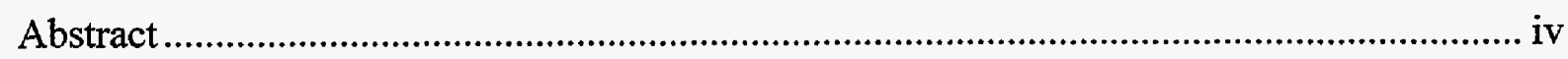

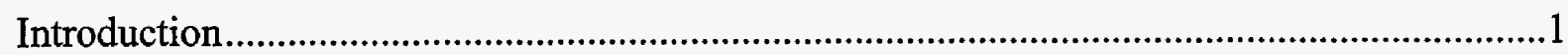

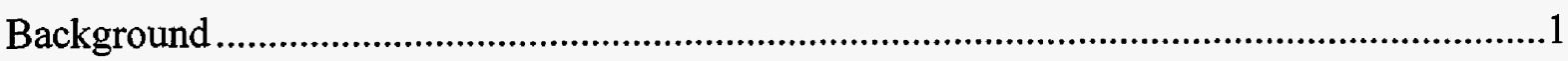

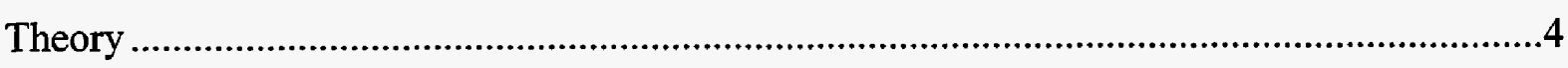

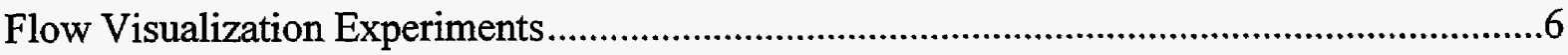

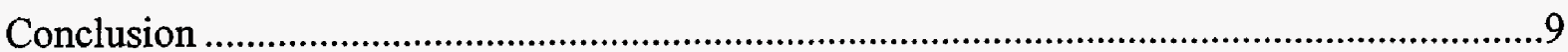

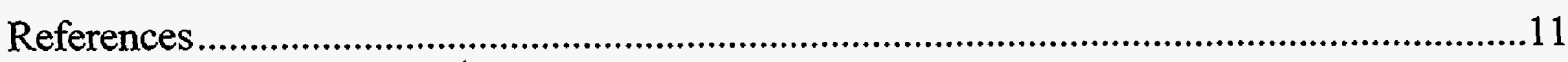




\title{
MULTIPHASE FLOW AND CAVERN ABANDONMENT IN SALT
}

\author{
Brian Ehgartner \& Vince Tidwell \\ Sandia National Laboratories* \\ Albuquerque, NM 87185-0706
}

\begin{abstract}
Although the depositional environment of salt is generally wet, many salt deposits (particularly domal salts) contain interstitial gas. It is hypothesized that the long-term state of an initially liquid filled cavern in gassy salt will be gas filled. With the interest in using caverns for waste disposal, the long-term stite of a cavern must be known. This raises such questions as: Under what conditions will $\xi$ as migrate into a salt cavern and alternatively, under what conditions will liquids imbibe into the salt? Over what time scales do these processes operate and what is the equilibriun state of a salt cavern?
\end{abstract}

To answer these questions, an understanding of the processes governing two-phase flow in salt is needed. Here, we consider the long term performance of salt caverns by way of a survey of pertinent literature followed by a brief review of first principles. To support these efforts a suite of simple laboratory experiments were conducted. In these experiments concurrent flow of gas and brine were investigated with the aid of light-transmission imaging, which allowed direct visualization of the flow of brine through thin slabs of salt.

Multiphase flow visualization experiments were conducted on both slightly damaged and intact salt core to provide data on two-phas a flow in salt over a range of permeabilities and porosities. The fact that two-phase flow was measured over relatively short time scales and small pressure gradients suggests that the mechanism of gas intrusion into a cavern and subsequent displacement of cavern fluid int's the salt is possible. Further study is needed to better quantify the multiphase flow properties relevant to cavern abandonment issues in salt.

\footnotetext{
* Work supported by U.S. Department of Energy, National Petroleum Technology Office, Tulsa, OK. Sandia is a multiprogram laboratory operated by Sandia Corporation, a Lockheed Martin Company, for the United States Department of Energy under Contract DE-AC04-94AL85000. Paper prepared for Fall Solution Mining Research Institute meeting, October 2000.
} 


\section{INTRODUCTION}

The presence of gas in salt is well documented. Most mines and caverns experience continuous gas intrusion, abrupt gas releases, or outbursts during their operational life. Gas intrusion is expected to continue after an underground excavation is plugged and abandoned. Typical cavern abandonment calls for filling the cavern with brine and cementing the wells. Because brine is easily saturated with gas, a gas cap may form after plugging and abandonment in salts that contain gas. The continued development of a gas cap would displace the brine or other cavern fluids into the salt.

Potential impact of such processes on waste disposal in caverns and hence waste migration must be understood. This paper will explore the hypothesis that an underground cavity in gassy salt will eventually be gas filled as is observed on a small scale in some naturally occurring salt inclusions: First, a summary is presented on what is known about gas occurrences, flow mechanisms, and cavern behavior after abandonment. Then, background information is synthesized into theory on how gas can fill a cavern and simultaneously displace cavern fluids into the surrounding salt. Lastly, two-phase (gas and brine) flow visualization experiments are presented that demonstrate some of the associated flow mechanisms and support the theory and hypothesis that a cavity in salt can become gas filled after plugging and abandonment.

\section{BACKGROUND}

The depositional environment of salts is commonly believed to be associated with a saltwater basin that has both a source of sea water and an evaporative process whereby the salinity of the brine concentrates to the point of salt precipitation. From a simplified perspective, changes to the basin and deposition of other rocks, soil, and debris many millions of years ago are believed to have buried the salt and provided a source of gas through organic decomposition. Thus the depositional environment is wet and sometimes gas is present in salt. In some cases, tectonic forces and the buoyant nature of salt (since salt is less dense than most geologic materials) has resulted in uplift and formation of salt domes. The origin of U.S. Gulf Coast domes and occurrence of gas is well documented (e.g., Martinez, 1991; Kupfer, 1978).

Salt domes along the Gulf Coast of the U.S. contain relatively pure salt. The salt is generally considered to be dry, containing gases that are 90 to 99 percent methane, and lesser amounts of other hydrocarbons and other gases (Iannacchione and Schatzel, 1985), although brine and other fluids are sometimes present. In addition to methane, other gases commonly found in salts include carbon dioxide and nitrogen (Baar, 1977; Dorfelt, 1966); however, practically all gases have been found (Brendiaux, 1966; Bakowski, 1966; Iannacchione and Schatzel, 1985).

Gimm and Pforr (1964) believe that a large part of the gases found in German potash mines is bound to the interstices between individual crystals (intergranular), and a smaller amount bound to the pores in the crystals (intragranular). Actual measurements showed that over 90 
percent of gas is included in the microscopic cavities at crystal boundaries through intergranular binding, and the rest of the gas within the crystals themselves (Gimm, Thoma, and Eckart, 1966). This was supported by gas measurements and observations taken during dissolution of salt in the laboratory and from gas releases during mining in U.S. Gulf Coast domes (Molinda, 1988). In the presence of brine, visual observations under the microscope show gas is stored as small bubbles at the intercrystalline boundaries (Urai, 1983). A review of the literature (Ehgartner, 1998) suggests that the volume of entrained gas (intragranular) content is quite small and the intergranular gas content is relatively large in comparison to entrained gas content (up to several orders of magnitude).

The permeability of salt is very low, on the order of a nanoDarcy $\left(10^{-21} \mathrm{~m}^{2}\right)$ or less, and pore pressures approach lithostatic in many cases (Ehgartner, 1998). The bedded salt in SE New Mexico was studied extensively prior to the storage of low level radioactive wastes at the Waste Isolation Pilot Plant (WIPP). The formation permeabilities as measured away from the air Intake Shaft ranged from $10^{-21}$ to $10^{-24} \mathrm{~m}^{2}$ (Knowles, Dale, and Hurtado, 1998). Similarly, permeabilities have been measures as low as $10^{-24} \mathrm{~m}^{2}$ at distance from mined openings in Germany (Belohlavek et al., 1999). The salt at WIPP is brine saturated with a pore pressure measured at lithostatic (Howarth et al., 1991; Beauheim, Saulnier, and Davies, 1991). Similar to WIPP, Gulf Coast salts are believed to be at lithostatic pore pressure (Kupfer, 1978; Baar, 1961 \& 1977) and measurements in the U.S. tend to support pressures approaching lithostatic (Iannacchione and Schatzel, 1985; Molinda, 1988). The permeabilities and porosities inferred at other locations throughout the world show considerable variability. Permeabilities vary by several orders of magnitude (Durup, 1991; Berest et al., 1996; Durup, 1994; Guarascia and Berest, 1999), while porosities range from slightly less than 1 percent for intact or undamaged salt (Sutherland and Cave, 1980; Stormont, 1990) up to 7 percent (Genantman, 1981).

The rates of gas intrusion measured in wellbores, mines, and caverns range from near instantaneous (outbursts) to very slow infiltration or percolation (Molinda, 1988; Iannacchione et al., 1984). In some cases the flow durations are limited, whereas other gas migration rates appear to continue for many years without any depletion. Gas intrusion rates have been measured in caverns at four Gulf Coast domes in the Strategic Petroleum Reserve program. The gas intrusion rates varied significantly between sites and caverns in a particular dome. Approximately one-half of the 60 oil-filled caverns had no measurable gas content, whereas the others averaged 10 million $\mathrm{ft}^{3} / \mathrm{yr}$, with some up to 80 million $\mathrm{ft}^{3} / \mathrm{yr}$ (Hinkebein et al., 1995). These rates have been insufficient to saturate the oil in the caverns (typically $10 \mathrm{MMB}^{1}$ ). Oil does not completely saturate with gas until the gas content is over $100 \mathrm{ft}^{3} / \mathrm{bbl}$. Brine more easily saturates with gas than petroleum products and will form a gas cap quicker since the solubility of natural gas is only 1 to $4 \mathrm{ft}^{3} / \mathrm{bbl}$ at typical cavern pressures and temperatures (Bradley, 1987). Brine saturation in wells and caverns is fairly common, for example (Hinkebein, 1998).

Differences in permeabilities, pore pressures, and relative saturation of pores (gas or brine) result in different cavern behaviors both before and after they are plugged. Theoretically, for a sealed cavern, equilibrium is reached when the creep closure in the lower portion of the

${ }_{1} 1 \mathrm{MMB}=1 \times 10^{6} \mathrm{bbl} ; 1 \mathrm{bbl} \sim 5.6 \mathrm{ft}^{3}$ 
cavern equals the volumetric expansion in the upper part. Because of differences in the densities of the cavern fluid (gas or brine) and surrounding salt, the pressures in the lower portion of a sealed cavern will be less than lithostatic while the pressures in the upper part of the cavern will be greater than lithostatic. The equilibrium state of a plugged cavern is illustrated in Figure 1 (Ehgartner, 1994).

The theoretical state may not be achievable because of brine migration from the cavern, as has been demonstrated in some wells and caverns. A one-year pressurization test in a well measured equilibrium pressures less than theoretical, but approaching lithostatic pressure (Durup, 1991). Berest and Brouard (1995) showed that when pore pressures in salt are less than lithostatic, cavern fluids may not achieve lithostatic pressure because of brine migration (percolation) out of the cavern. The pressure monitored in a plugged cavern showed that equilibrium pressure was controlled by equilibrium of creep closure with brine outflow (Berest et al., 1999). The equilibrium pressure in the cavern was significantly smaller than lithostatic pressure and slightly above the hydrostatic (Durup et al., 1998).

The other mechanism that contributes to a less than theoretical pressure is the potential for enhanced permeability due to overpressurization of the pores at the upper portion of the cavern. Laboratory tests (Fokker, 1995; Fokker et al., 1993; and Kentor et al., 1990) measured a permeability increase in salt when fluid pressures increased over the confining or lithostatic stress. Changes in the degree of saturation of salt can also effect the creep rate of the salt and hence cavern pressurization rates. At moisture levels less than saturated, the creep and strength of salt is known to be a function of its saturation content (Horseman, 1984). Experimentally, the acceleration of creep with brine saturation has been documented by a number of investigators (Urai et al., 1986). It is argued that this effect will increase at strain rates below those attainable in the laboratory (Urai, 1983) which represents conditions after plugging and abandonment.

To date, analyses of plugged and abandoned caverns have assumed brine-filled caverns, and some analyses have considered waste disposal (Gehle et al., 1999). The response of a cavern due to gas has not been simulated. However, the presence of a gas cap would reduce the compressibility of the cavern and hence its pressurization rate due to creep closure. Such behavior has been observed in caverns at Carresse (Berest et al., 1997) and at Bryan Mound (Ehgartner, 1996) where gas caps were observed in sonar surveys and their presence analytically verified by the low compressibility of the caverns.

Much progress has been made in understanding the geotechnical processes occurring in a plugged cavern (Behrendt and Crotogino, 1997). Very little attention has been focused to date on the significance of gas, probably because its occurrence in salt is not universal and its role and associated mechanisms are not well understood. 


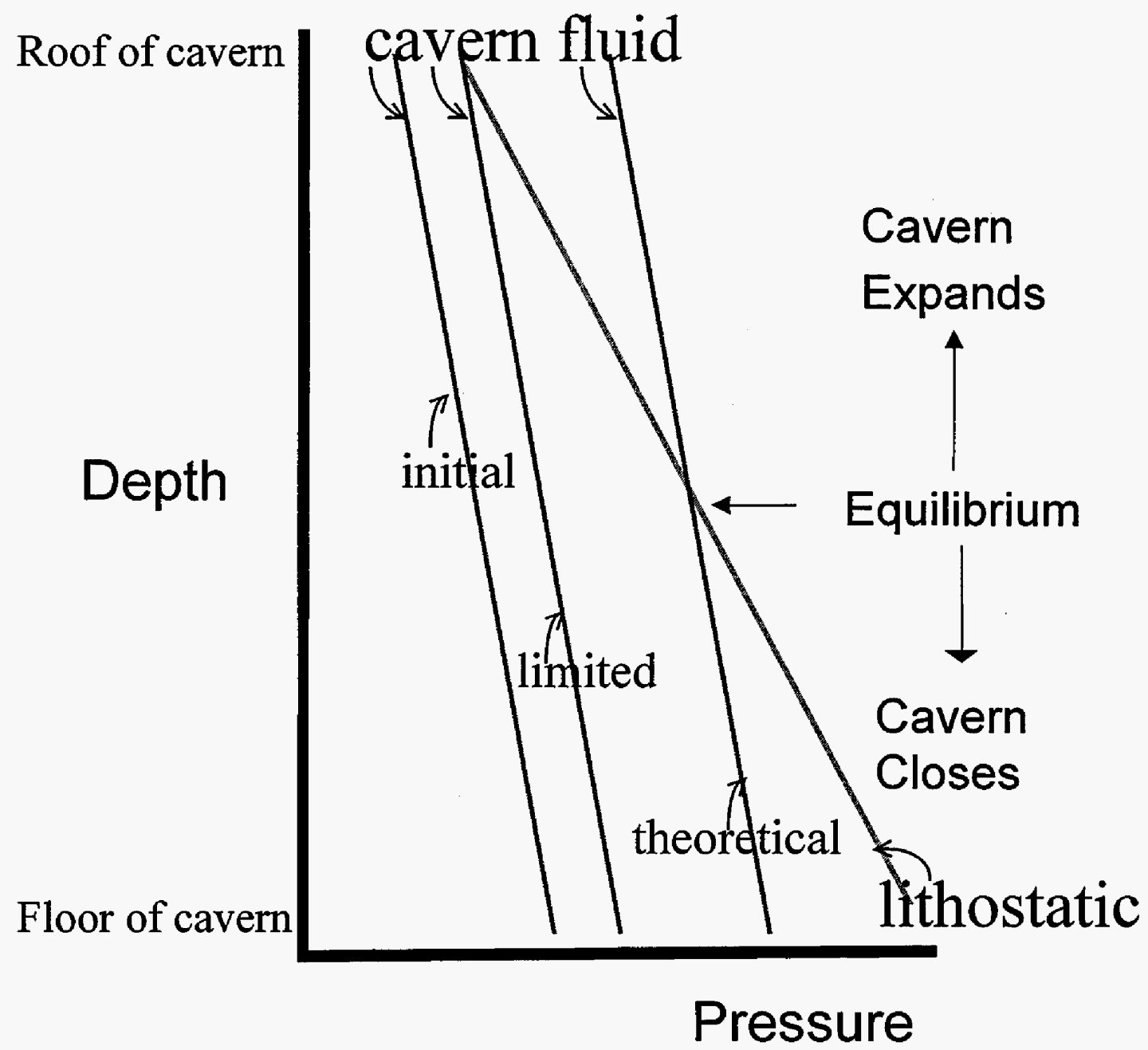

Figure 1. Cavern pressures relative to lithostatic after sealing. Initially, cavern pressures are at hydrostatic. Theoretically, creep closure of the cavern will pressurize the cavern fluid to equilibrium with lithostatic pressure, but theoretical cavern pressures may be limited due to brine migration from the cavern.

\section{THEORY}

To facilitate predictive modeling, salt is often generalized as being either saturated with brine or gas. Rather than dealing with the coupled nonlinear gas/brine flow equations, the hydraulic system is typically simplified to the point of using Darcy's law. This approach is of concern for two reasons. First, brine and gas are both commonly present in these systems and the mobility of one phase depends on the other. Second, Darcy's law ignores key physical processes governing concurrent gas and brine flow (e.g., capillarity, phase entrapment, hysteresis). Field and laboratory data suggest that Darcy's law is only appropriate for modeling flow through salt under very limited circumstances. 
Cosenza et al. (1996 and 1999) performed gas and brine injection tests in a borehole located in a relatively pure salt layer. For brine percolation, the leakage was relatively well simulated by a model based on Darcy's law. On the other hand, gas permeation did not follow Darcy's law, but appeared to be controlled by the Knudsen effect (diffusion) and partial saturation was thought to play an important role. Similar results were obtained from analyses performed of a long-term ( $1 \mathrm{yr}$ ) well test that progressively increased gas and brine pressure in the well bore and measured subsequent pressure decays (Durup, 1994). The brine percolation rates obeyed Darcy's law, but gas inflow remained constant over the pressure changes. These observations suggest that the salt in both experiments was initially wet. In the dry Gulf Coast domal salt, gas flow appears to follow Darcy's law. Measured gas intrusion rates into the SPR caverns have been simulated assuming Darcy flow (Ehgartner, 1998). Froehlich et al. (1995) found that gas transport can be governed by either permeation (Darcy's law) or by normal diffusion, depending on the salt properties.

To fully understand the long-term behavior of gas and brine in abandoned salt caverns one must refer to the fundamentals of two-phase flow physics. In this system brine forms the wetting phase and gas the non-wetting phase, hence gas will preferentially fill the largest pores in the system at equilibrium. Thus under conditions of unrestricted gas/brine flow, the cavern should fill with that gas available in the formation.

There are three different flow regimes potentially important to an abandoned salt cavern. A single cavern may be host to any or all three of these regimes. In the first regime gas flow dominates. Pore pressures in the formation exceed both the cavern pressure and the capillary pressure (potential for salt to imbibe brine). Because of the small pore structures in salt, the capillary forces are quite large and have been theoretically estimated to range from 100 to over 1,000 psi (Cosenza et al., 1995). Such conditions are likely to occur in the lower reaches of the salt cavern where pore pressures are significant.

The second regime is characterized by concurrent gas and brine flow. Here pore pressures still exceed the cavern pressure hence gas flows from the salt to the cavern. However, pore pressures do not exceed the capillary pressure, so brine is able to imbibe into the salt. This situation commonly occurs in the intermediate reaches of the cavern.

The third regime is dominated by brine flow. Cavern pressures exceed pore pressures, thus brine flows into the formation under the combined effect of advection and capillarity. However, the brine must displace gas present in the salt. The gas will either migrate to the cavern or will become trapped thus limiting the flow of brine. This regime is likely to occur in the upper reaches of the cavern.

Fundamentally, one would predict the long-term state of an abandoned cavern in gassy salt to be gas filled. However, there are many other considerations that will effect the behavior of the system as well as control the time scales over which these processes operate. For example, the relative permeability and capillary pressure characteristics of the salt will greatly influence the rate and extent of gas and brine flow. Capillary trapping could potentially limit the flow of gas and/or brine. Hysteretic effects, as induced by changes in cavern operating pressures or changes of cavern liquids, could likewise play an important 
role in brine and gas flow. Also of concern is the degree of coupling between the processes governing the mechanical and hydrologic behavior of the salt. In efforts to begin addressing some of these issues we present below a suit of laboratory experiments aimed at better understanding the physics governing brine/gas flow in salt.

\section{FLOW VISUALIZATION EXPERIMENTS}

Above, a brief discussion was presented on multiphase flow processes potentially important to the long-term behavior of gas and brine in abandoned salt caverns. To elucidate some of these processes, a suite of simple laboratory experiments was performed. Experiments employed light-transmission imaging, which provided a unique opportunity to visualize multiphase flow in thin slabs of salt.

Two core samples taken from the Weeks Island salt dome formed the basis of our study. One core was used in its "as received" state and thus provides a sample of mildly damaged salt. The other core was subjected to 2175 psi pressure for over 30 days to heal any damage caused by the coring process. This second sample is taken to represent salt of an approximate intact state. Slabs measuring $8.9 \times 8.5$ by $2.5 \mathrm{~cm}$ were sectioned from each core. To avoid damaging the salt while sectioning the slabs, a precision wire-line saw $\left(2.5 \times 10^{-4} \mathrm{~cm}\right.$ diameter diamond impregnated wire) was used.

Upon sectioning the samples, the two slabs were mounted in a flow cell. The cell consisted of an aluminum frame sandwiched between two thin sheets of Plexiglas (Figure 2). The Plexiglas faceplates were sealed to the salt slabs and frame with epoxy. To allow pressurization of the test cell, the fixture was sandwiched between two 2-cm thick glass plates held rigidly in place by a metal frame. The test cell accommodated flow manifolds on opposing edges of each salt slab. The manifolds allowed control of the brine/gas boundary conditions prescribed for each test.

A suite of three experiments was conducted on each salt slab. The intent of the first experiment was to characterize the permeability of the initial air-dry state of the salt. The test involved prescribing the gas pressure along one edge of the salt slab while venting the other edge (manifold) to the atmosphere. Tests were conducted with an injection pressures of 15 psi. Unfortunately, the resulting flow rates were all well below the sensitivity of available gas flow sensors. Accordingly, we conclude that the permeability of both slabs is less than $1 \times 10^{-}$ ${ }_{18} \mathrm{~m}^{2}$ (the lower limit of our current equipment). Efforts are currently being made to characterize scrap from the cut salt cores using more sophisticated equipment.

The second test involved concurrent flow of gas and brine through each salt slab. This test was designed to investigate the case where the pore pressure in the salt (i.e., gas phase) exceeds the cavern brine pressure, but is less than the capillary pressure of the initially dry salt. The experiment involved prescribing a constant gas pressure of 6 psi along one edge of the salt slab while brine at approximately atmospheric conditions was prescribed along the opposing boundary. The brine used in this test consisted of a 5 molar $\mathrm{NaCl}$ solution that was 
equilibrated with crushed rock salt for seven days prior to the experiment. To enhance visibility of the brine, $5 \mathrm{mg} / \mathrm{l}$ of FD\&C Blue \#1 food color was added to the solution.

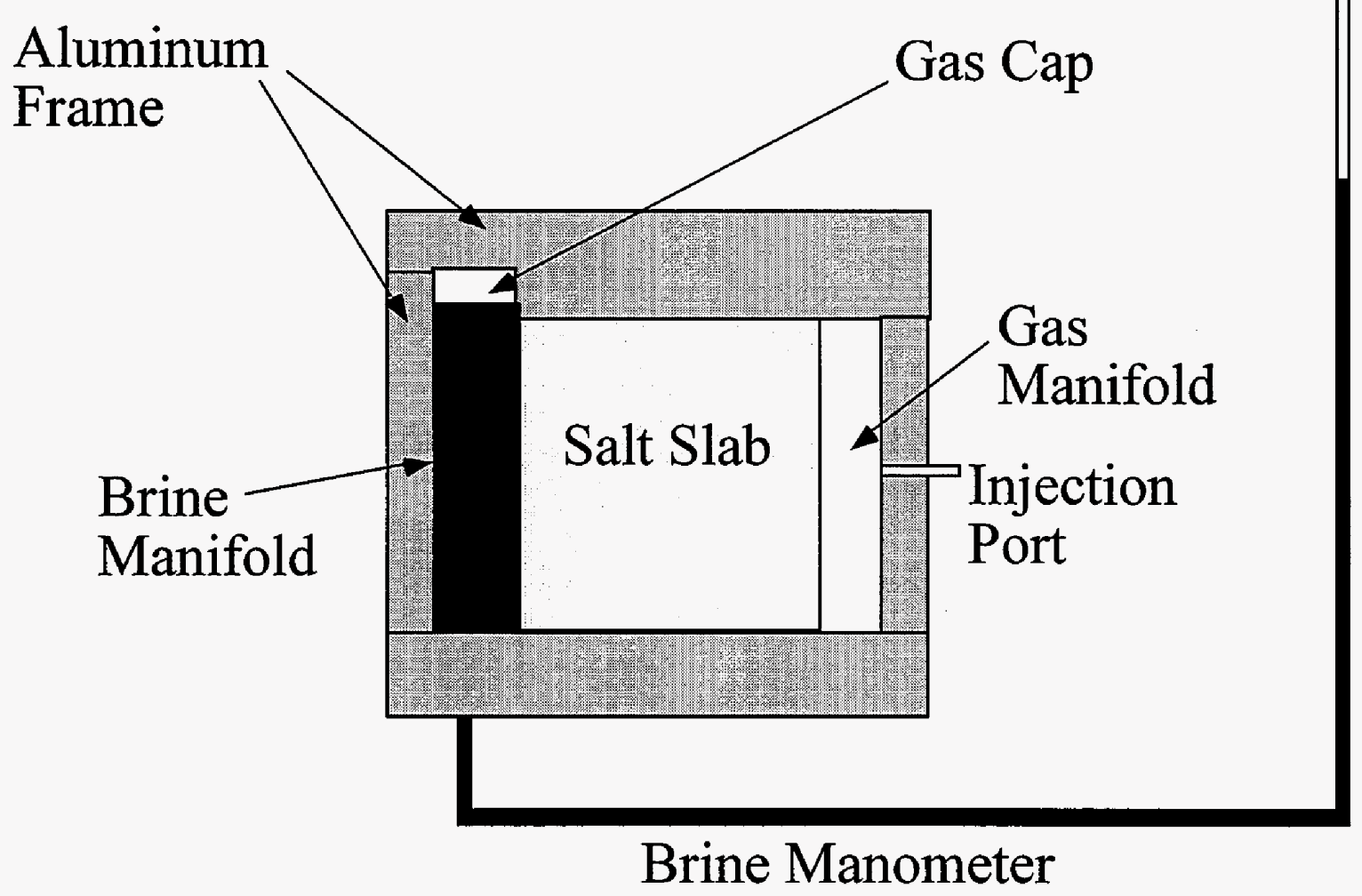

Figure 2. Flow cell schematic.

Throughout the duration of the experiment, measurements of both the gas flow and brine imbibition were made. Gas flow across a salt slab was realized by the formation of a gas cap in the top of the opposing manifold containing the brine. Displacement of the brine by the gas cap was subsequently measured in the manometer connected to the brine manifold (see Figure 2). In Figure 3, brine displacement is plotted as a function of time for both salt slabs. From these graphs it is evident that gas flow occurred across both salt slabs, albeit at a significantly higher rate for the case of the damaged salt slab.

Key to this effort was the ability to visualize concurrent brine flow in the salt slabs. Visualization was accomplished by means of light-transmission imaging (Tidwell and Glass, 1994). This involved placing the test cell in front of a computer stabilized bank of highintensity fluorescent light tubes. The light transmitted through the salt slabs was subsequently digitized with the aid of a Charged-Couple Device (CCD) camera (Photometrics with a Kodak KAF-4200 Scientific Grade CCD). 


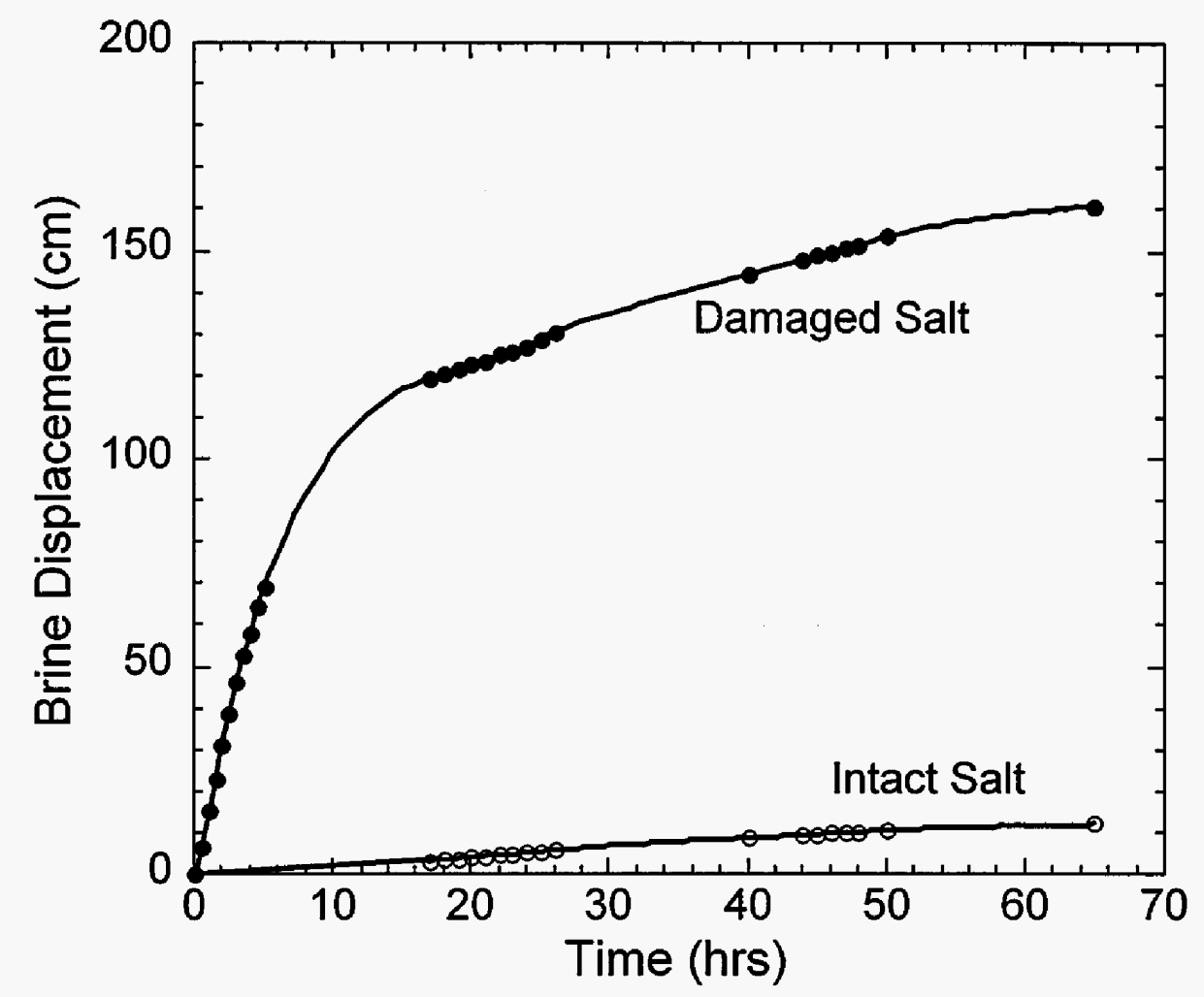

Figure 3. Cross-slab gas flow as measured by the displacement of brine vertically in the manifold manometer (see Figure 2). As gas flowed into the brine manifold a gas cap formed that subsequently forced brine out of the manifold and into the manometer.

Specifically, the two-dimensional light field transmitted through each salt slab was digitized into an array of 809 by 773 pixels yielding a spatial resolution of 0.11 by $0.11 \mathrm{~mm}$ per pixel. Each pixel was assigned a value between 0 and 4095 depending on the transmitted light intensity at that point.

Light transmission images were acquired of the initially dry salt slabs and then periodically throughout the duration of the experiment. Changes in the brine saturation (integrated over the thickness of the slab) at each point in the image are measured as a corresponding decrease in the light intensity. To extract these changes in brine saturation from the data, processing of the images is required. First, alignment of each image is checked to assure that the position of the test cell has not changed by more than 0.1 pixels. Second, each image is adjusted for small temporal variations in light source intensity. This is accomplished by normalizing each image according to a stepped intensity wedge included in every image. Third, images are acquired in suites of ten (acquisition time for a single image is approximately 5 seconds), which are subsequently averaged together to reduce effects of camera noise. Finally, each image is subtracted from the initially dry image to yield a two-dimensional map of the brine in the salt slabs. Because of the very low porosity of the salt we have not attempted to quantify the 
brine saturation in these images (see Tidwell and Glass, 1994); however, we plan to explore more quantitative imaging approaches in the future.

In Figure $4 \mathrm{a}$ and $4 \mathrm{~b}$ light transmission images showing the imbibition of brine into the damaged salt core are shown. Recall that the conditions under which these images were taken involved concurrent gas flow (see Figure 3) in the opposite direction to the brine imbibition. Although slow, brine imbibition is distinct and persistent. Close inspection of the relative brine saturation fields reveals a geometric structure. This structure corresponds closely to the network of boundary planes distinguishing the individual salt crystals in the salt slab. From this we infer that the measurable brine flow was restricted to the bounding planes between salt crystals (intergranular flow). This behavior is particularly evident upon direct visual inspection of the salt slab.

Imbibition of brine into the intact salt slab was also evident by way of visual inspection. Both the rate and extent of imbibition were considerably less than that measured for the damaged core (i.e., consistent with the gas flow results in Figure 3). Because of the lower porosity of the intact salt we were unable to resolve the brine flow with the light-transmission imaging. However, brine imbibition was evident in a number of the planes bounding individual salt crystals.

In the final test, brine flow continued uninterrupted while the gas pressure was reduced to atmospheric conditions after 2.92 days (i.e., gas flow was discontinued). This test represents conditions where the pore and cavern pressures are roughly equal. Figures $4 \mathrm{c}$ and $4 \mathrm{~d}$ present the light-transmission images of the brine flow for this period of time. Persistent brine flow is again evident with little change in the rate or extent with the changing boundary condition. Similar results were noted for the intact salt core and again the brine concentration remained too small to be resolved by light-transmission imaging.

It is interesting to note that the brine saturation images are not marked by an abrupt change when the gas pressure was dropped to atmospheric conditions. That is, the gas flow paths, which should fill relatively quickly with brine, were not readily apparent in the images. This suggests a relatively narrow pore size distribution and/or a tortuous and dispersed flow path for the gas.

\section{CONCLUSIONS}

The implications of a gas cap or the complete gas fill of a cavern have not yet been adequately considered in the abandonment of a cavern, in part because the process has not been recognized and the mechanisms are not well understood. A review of the literature, cavern processes and two-phase flow mechanisms, and the flow visualization experiments presented herein suggest that it is possible that the long-term state of an abandoned cavern will be gas filled when gas is present in salt. Further research on two-phase flow in salt is needed to be able to quantify this process, so that the significance of its impacts on cavern storage and abandonment can be understood. 


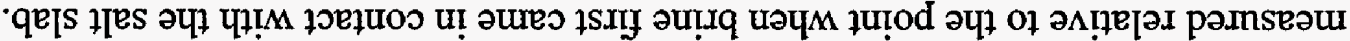

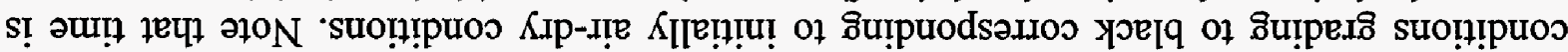

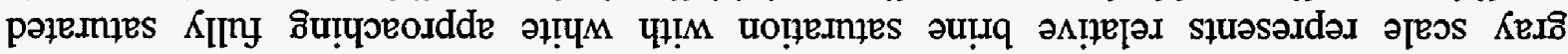

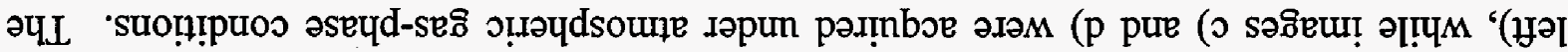

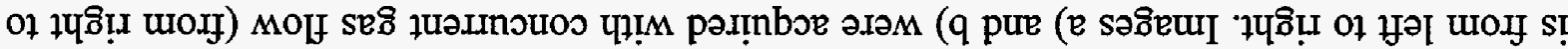

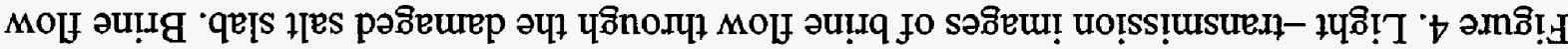
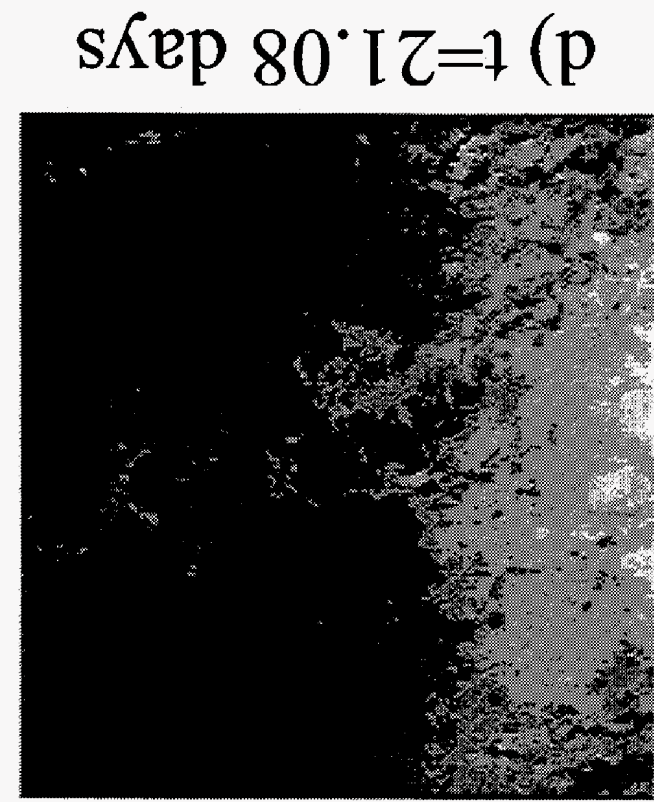

$\operatorname{s\kappa ep~} Z 6^{\circ} Z=7(q$

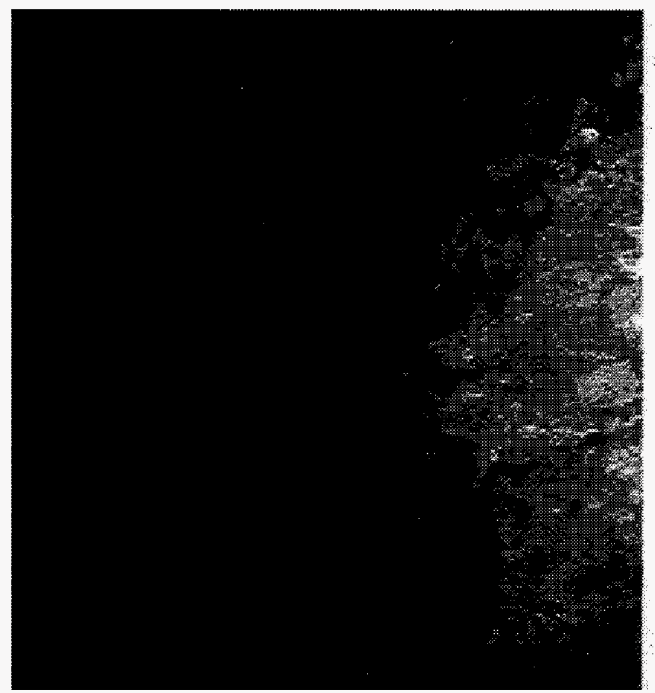

SKep $80^{\circ} Z I=7(0$

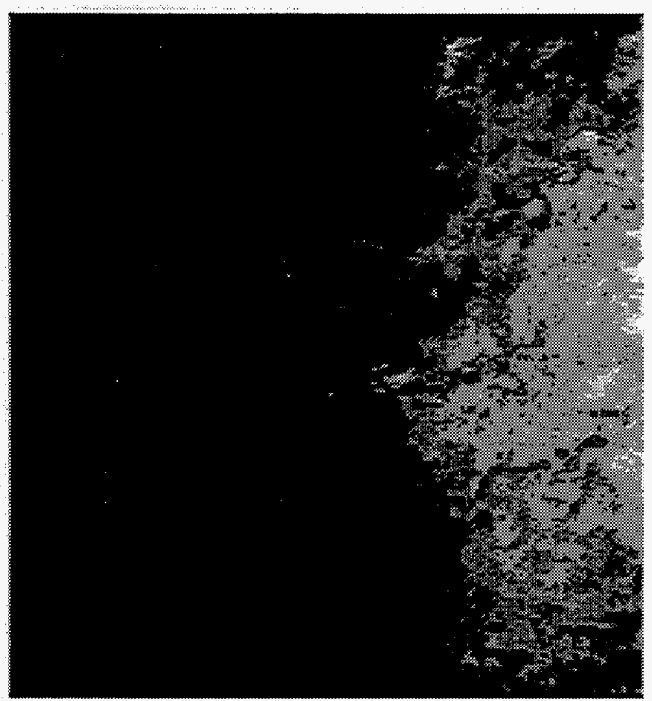

sKep ZI ${ }^{\circ} 0=\mathfrak{l}(\mathrm{e}$

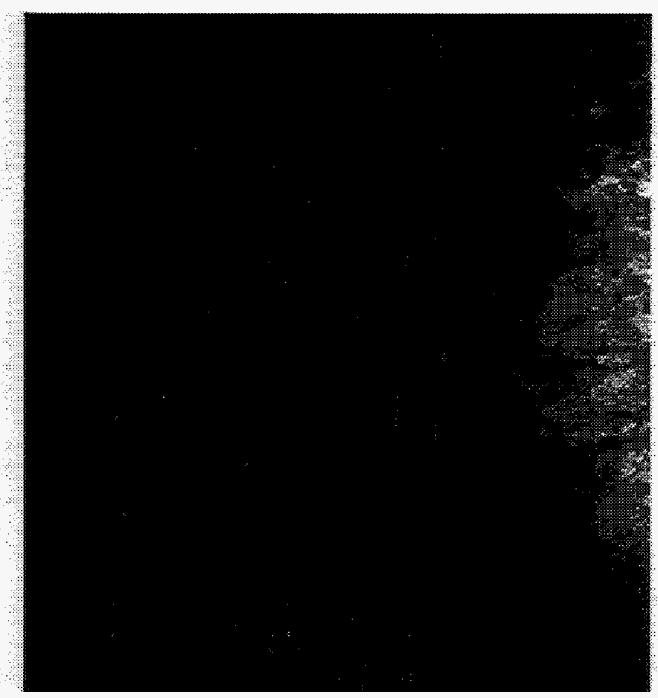




\section{$\underline{\text { References }}$}

Baar, C.A. Measurements of Rock Pressure and Pillar Loads in Deep Potash Mines, 2nd Symposium on Salt, Vol. 2, The Northern Ohio Geologic Society, Cleveland, Ohio, 1961.

Baar C.A. Applied Salt Rock Mechanics, I. Elsevier Sci. Pub. Co., NY, NY, 1977.

Behrendt, C. and F. Crotogino. SMRI Bibliography for Cavern Abandonment Research Program, KBB, Hannover, 1997.

Belohlavek, K-U, A. Behr, S. Foerster, and F. Haefner. In-Situ Determination of Geohydraulic parameters of natural Sait Rocks for Gas Loosening Zones Around Drifts (Cavities). SMRI Spring Meeting, Apri1 11-14, Las Vegas, 1999.

Berest, P. and B. Brouard. Behavior of Sealed Solution-Mined Caverns. SMRI Spring Meeting, New Orleans, 1995.

Berest, P., J. Bergues, B. Brouard, G. Durup, and B. Guerber. A Tentative Evaluation of the MIT. SMRI Spring Meeting, Houston, April 1996.

Berest, P., B. Brouard, J. Bergues, J. Frelat, and G. Durup. Salt Caverns and the Compressibility Factor. Technical paper presented at the Fall Solution Mining Research Institute meeting, El Paso, TX, October 5-8, 1997.

Berest, P., J. Bergues, B. Brouard, J.G. Durup,, B. Guerber. A Salt Cavern Abandonment Test. SMRI Spring Meeting, April 1114, Las Vegas, 1999.

Beauheim, R.L., G.J.Saulnier, Jr, and J.D. Davis. Interpretation of Brine-Permeability Tests of the Salado Formation as the Waste Isolation Pilot Plant Site: First Interim Report. SAND90-0083, Sandia National Laboratories, Albuquerque, NM, August 1991.

Bradley, H.B. (Editor-in-Chief). Petroleum Engineering Handbook. Society of Petroleum Engineers, Richardson, TX, Third Ed., 1987.

Brendiaux, J. Investigations of Foot-wall-bursts and Gas-effusions in the State Potash-mines of Alsace. International Congress on Problems of Sudden Outbursts of Gas and Rock. Leipzig, German Democratic Republic, October, 1966.

Cosenza, P, M. Ghoreychi, and B. Bazargan-Sabet. In Situ Gas and Brine Permeability Measurements in Salt. Proc. 4th Conf. Mechanical Behavior of Salt, Trans. Tech Publications, Montreal, 1996.

Cosenza, P, M. Ghoreychi, B. Bazargan-Sabet, and G. deMarsily. In Situ Salt Permeability measurements for Long Term Safety Assessment of Storage, International Journal of Rock Mechanics and Mining Sciences, v. 36, no.4, June 1999.

Cosenza, P, M. Ghoreychi, and B. Bazargan, S. Telandro, and A Cournut. First Results and Interpretation of In Situ Permeability Measurements in Salt to Gas and to Brine. Proc. 5th Progress meeting PEGASUS (Project on Effects of Gas in Underground Storage Facilities for Radioactive Waste) Office for Official Publications of the European Communities, EUR16796, pp 167-175, Rapolano Terme, June 1995.

Dorfelt, H. Sudden Outbursts of Gas and Rock in the Mining of the GDR in Relation to the Safety in Mines. International Congress on Problems of Sudden Outbursts of Gas and Rock. Leipzig, German Democratic Republic, October, 1966.

Durup, J.G. Long Term Permeability Field Test in Rocksalt, Gaz de France, La Plaines St. Denis, France, 1991.

Durup, J.G. Long-Term Tests for Tightness Evaluations with Brine and Gas in Salt. SMRI Fall Meeting, Hanover, 1994.

Durup, J.G., B. Guerber, P. Berest, J. Bergues, B. Brouard, V. de Greef, Y. Le Bras. Long Term Evolution of a Sealed Cavern. SMRI Fall Meeting, October 4-7, Rome, 1998.

Ehgartner, B.L. Long-Term Sealing Analyses for US Strategic Petroleum Reserve (SPR) Caverns. SAND92-2891, Sandia National Laboratories, Albuquerque, NM, 1994.

Ehgartner, B.L. Bryan Mound Cavern 2 (Gas Cap). Internal report. Sandia National Laboratories, Albuquerque, NM, January 19 , 1996.

Ehgartner, B.L. J.T. Neal, T.E. Hinkebein. Gas Releases from Salt. SAND98-1354, Sandia National Laboratories, Albuquerque, NM, June 1998.

Fokker, P.A. The Behavior of Salt and Salt Caverns. PhD Thesis, Technische Universiteit Delft, 1995. 
Fokker, P.A., C.J. Kentor, and H.P. Rogaar. The Effect of Fluid Pressures on the Mechanical Stability of (Rock) Salt. 7th Symposium on Salt, Elsevier Science Publishers, Amsterdam, 1993.

Froehlich, H., C. Hohenthanner, S. Foerster, W. Drees, and J. Bruck. Determination of the Diffusion and Permeability Behavior of Hydrogen in Rock Salt and Compacted Salt Gravel. Technische Hochschule Darmstadt (DE). Technische Univ. Bergakademie Freiberg (DE), Dec. 1995.

Gehle, R.M., R.L. Thoms, and C.L. Brassow. Analyses of Salt Caverns with Granular Wastes. SMRI Spring Meeting, Apri1 11-14, Las Vegas, 1999.

Genantman, L.H., editor. Physical Properties Data for Rack Salt. U.S. Dept. of Commerce, National Bureau of Standards, Monograph 167, January, 1981.

Gimm W. and H. Pforr. Breaking Behavior of Salt Rock Under Rockbursts and Gas Outbursts. 4th International Conference on Strata Control and Rock Mechanics, Columbia University, NY, May 4-8, 1964.

Guarascio, M. and P. Berest. Salt Permeability: A Synthesis of the Rome Panel Discussion. SMRI Spring Meeting, April 11-14, Las Vegas, 1999.

Hinkebein, T.E., S.J. Bauer, B.L. Ehgartner, J.K. Linn, J.T. Neal, J.L. Todd, P.S. Kuhlman, C.T. Gniady, H.N. Giles. Gas Intrusion into SPR Caverns. SAND 94-0023, Sandia National Laboratories, Albuquerque, NM, Dec. 1995.

Hinkebein, T.E. Considerations of the Gas Content of Brine Entering the Weeks Island Mine. Sandia National Laboratories technical memorandum to G. Berndsen, Dept. of Energy, dated February 5, 1998.

Horseman, S.T. Moisture Content- A Major Uncertainty in Storage Cavity Closure Prediction. 2nd Conf. On the Mechanical Behavior of Salt, Hanover, 1984.

Howarth, S.M., E.W. Peterson, P.L. Lagus, K-H. Lie, S.J. Finley, and E.J. Nowak. Interpretation of In-Situ Presure and Flow Measurements of the Salado Formation at the Waste Isolation Pilot Plant. SPE21840, Society of Petroleum Engineers, Richardson, TX, 1991.

Iannacchione, A., R. Grau, A. Sainato, T. Kohler, and S. Schatzel, Assessment of Methane Hazards in an Anomalous Zone of a Gulf Coast Salt Dome. Bureau of Mines Report of Investigations RI- 8861, U.S. Dept. of the Interior, 1984.

Iannacchione, A.T. and S.J. Schatzel. Characterization of the Occurrence of Methane in Gulf Coast Domal Salt Mines. 2nd U.S. mine Ventilation symposium, Reno, NV, 1985.

Kentor, C.J., S.J. Doig, .P. Rogaar, P.A. Fokker, and D.R. Davies. Diffusion of Brine Through Rock Salt Roof of Caverns. SMRI Fall meeting, Paris, 1990.

Knowles, M.K., T. Dale, and L.D. Hurtado. Hydraulic Characterization Activities in Support of the Shaft-Seals Fluid-Flow Modeling Integration into the WIPP EPA Compliance Certification Application. SAND98-0001, Sandia National Laboratories, Albuquerque, NM, 1989.

Kupfer, D.H. Problems Associate with Anomalous Zones in Louisiana Salt Stocks, USA, 119-134, Fifth International Symposium on Salt, The Northern Ohio Geological Society, Cleveland, Ohio, 1978.

Martinez, J.D. Salt Domes. American Scientist, Vol. 79, p 420-431, September-October, 1991.

Molinda, G. Investigation of Methane Occurrence and Outbursts in the Cote Blanche Domal Salt Mine, Louisiana. Bureau of Mines Report of Investigations RI- 9186, U.S. Dept. of the Interior, 1988.

Stormont, J.C. Gas Permeability Changes in Rock Salt During Deformation, Ph.D. Dissertation, University of Arizona, Tucson, AZ, 1990.

Sutherland, H.J. and S.P. Cave. Argon gas permeability of New Mexico rock salt under hydrostatic compression, Int. J. Rock Mech. Min. Sci. Geomech. Abstr., 17, 1980.

Tidwell, V.C., and R.J. Glass, X-ray and visible light transmission for laboratory measurement of two-dimensional saturation fields in thin-slab systems, Water Resources Research, 30(11), 2873-2882, 1994.

Uria, J.L. Deformation of Wet Salt Rock. Thesis, Utrecht: Univ., 1983.

Uria, J.L., C.J. Spiers, H.J. Zwart, and G.S. Lister. Weakening of Rock Salt by Water During Long-Term Creep. Nature Vol. 324, Dec. 11, 1994. 